\title{
Penerapan Jaringan Saraf Tiruan dalam Menentukan Kelayakan Calon Penerima Bantuan Renovasi Rumah pada Kantor Pangulu Nagori Tangga Batu Dengan Metode Backpropogation
}

\author{
Chyntia Irwana1 ${ }^{1}$ M.Safii ${ }^{2}$, Iin Parlina ${ }^{3}$ \\ Program Studi Sistem Informasi, STIKOM Tunas Bangsa Pematangsiantar \\ Jln. Jenderal Sudirman Blok A No.1,2,3 Pematangsiantar \\ e-mail: chyntiairwana1@gmail.com
}

\begin{abstract}
Home is one of the basic needs for humans, where the house serves as a place to shelter and shelter. Apart from having a function as a place to live, the house also functions as a place for fostering and chatting with a family. Poverty is a condition where a person is unable to fulfill his basic needs. In Nagori Tangga Batu there are still many people who have homes that are not habitable. Based on these problems, the government organized a poverty alleviation program through a home renovation route for residents of Nagori Tangga Batu village. In determining whether or not a house is suitable for renovation, it is necessary to use an Artificial Neural Network using the Backpropogation algorithm to determine whether or not the house of Nagori Tangga Batu residents is eligible for home renovation assistance. The best research with Artificial Neural Network method in determining the feasibility of recipients of home renovation assistance using the backpropagation algorithm is the model 6-3-1 with the repetition process (epoch) during training with epoch value $=1673$ and MSE achievement during testing with MSE $=0.00797068$. This research is expected to be a reference for further researchers relating to the user algorithm used.
\end{abstract}

Keywords : Renovation, Houses, Artificial Neural Networks, Backpropagation.

Abstrak - Rumah merupakan salah satu kebutuhan pokok bagi manusia, dimana rumah berperan sebagai wadah untuk bernaung dan tempat berlindung. Selain memiliki fungsi sebagai tempat tinggal, rumah juga berfungsi untuk tempat pembinaan dan bercengkrama suatu keluarga. Kemiskinan merupakan kondisi dimana seseorang tidak mampu untuk memenuhi kebutuhan dasarnya. Pada Nagori Tangga Batu masih banyak warga yang memiliki rumah tidak layak huni. Berdasarkan permasalahan tersebut, pemerintah menyelenggarakan program pengentasan kemiskinan melalui jalur renovasi rumah bagi warga desa Nagori Tangga Batu. Dalam menentukan layak atau tidak rumah warga untuk di renovasi, Hal tersebut diperlukannya sebuah Jaringan Saraf Tiruan menggunakan algoritma Backpropogation untuk mengetahui layak atau tidaknya rumah warga Nagori Tangga Batu mendapatkan bantuan renovasi rumah. Penelitian yang terbaik dengan metode Jaringan Syaraf Tiruan dalam menentukan kelayakan calon penerima bantuan renovasi rumah menggunakan algoritma backpropagation adalah model 6-3-1 dengan proses perulangan (epoch) pada saat pelatihan dengan nilai epoch $=1673$ dan pencapaian $M S E$ pada saat pengujian dengan MSE $=\mathbf{0 . 0 0 7 9 7 0 6 8}$. Penelitian ini diharapkan dapat menjadi referensi bagi peneliti selanjutnya yang berkaitan dengan pengguna algoritma yang digunakan.

Kata Kunci : Renovasi, Rumah, Jaringan Saraf Tiruan, Backpropogation. 


\section{PENDAHULUAN}

Jaringan Saraf Tiruan yang berupa susunan sel-sel saraf tiruan (neuron) dibangun berdasarkan prinsip-prinsip organisasi manusia, selain itu jaringan saraf tiruan dapat memprediksi kelayakan calon peneriman bantuan renovasi rumah yang dilakukan proses pelatihan menggunakan jaringan saraf tiruan dengan metode Backpropogation. Rumah merupakan salah satu kebutuhan pokok bagi manusia, dimana rumah berperan sebagai wadah untuk bernaung dan tempat berlindung. Selain memiliki fungsi sebagai tempat tinggal, rumah juga berfungsi untuk tempat pembinaan dan bercengkrama suatu keluarga. Setiap manusia pasti berkeinginan memiliki rumah yang layak untuk ditinggali, agar penghuni rumah merasa aman dan nyaman saat menempati rumahnya. Namun keinginan memiliki rumah yang layak bagi beberapa orang harus terpendam disebabkan oleh kemiskinan. Kemiskinan merupakan kondisi dimana seseorang tidak mampu untuk memenuhi kebutuhan dasarnya. Pada Nagori Tangga Batu masih banyak warga yang memiliki rumah tidak layak huni. Berdasarkan permasalahan tersebut, pemerintah menyelenggarakan program pengentasan kemiskinan melalui jalur renovasi rumah bagi warga desa Nagori Tangga Batu. Program ini memberikan bantuan berupa uang tunai kepada warga, kemudian dilakukannya pembelian material bangunan. Dalam proses seleksi bantuan, pihak bedah rumah akan berkoordinasi dengan semua gamot untuk memberikan rekomendasi dan data warga yang dianggap layak untuk mendapatkan bantuan perbaikan rumah. Setelah data warga dari masing-masing Huta terkumpul, maka tim bedah rumah akan melakukan tinjauan langsung ke rumah warga yang sudah di data untuk mengecek serta menilai keadaan dinding rumah, atap, MCK, dan lantai [1].

Jaringan Saraf Tiruan merupakan salah satu representasi buatan dari otak manusia yang selalu mencoba untuk mensimulasikan proses pembelajaran pada otak manusia tersebut [2]-[4]. Backpropagation merupakan salah satu dari banyaknya algoritma jaringan syaraf tiruan (JST) yang dapat digunakan untuk memprediksi dengan cara mempelajari data secara terbimbing [5]-[11]. Untuk mementukan layak atau tidak rumah warga Nagori Tangga Batu diproses berdasarkan kriteria dan alternatif yang dirancang oleh penulis dengan memanfaatkan Algoritma Backpropogation. Dalam penulisan karya ilmiah, penulis menggunakan kriteria Penghasilan/bulan, Status Tanah, Jenis Lantai, Jenis Dinding, MCK, Jenis Atap.

\section{METODOLOGI PENELITIAN}

\subsection{Analisa Data}

Pada Penelitian ini dilakukan di Kantor Pangulu Nagori Tangga Batu. Data penelitian diperoleh dengan melakukan observasi dan wawancara kepada pihak instansi. Data yang terkumpul selanjutnya diolah menggunakan Jaringan Saraf Tiruan dengan menggunakan metode Backpropogation. Kemudian diuji dengan Software Matlab R2011a. Data Penelitian diperoleh dari Kantor Pangulu Nagori Tangga Batu, Kecamatan Hatonduhan, Kabupaten Simalungun. Data penerima bantuan renovasi rumah pada Kantor Pangulu Nagori Tangga Batu dari tahun 2016 - 2017 yang terdiri dari 42 data. 
Tabel 1. Daftar Krieria

\begin{tabular}{|c|c|l|l|c|}
\hline No & Kriteria & \multicolumn{1}{|c|}{ Range } & \multicolumn{1}{c|}{ Keterangan } & Bobot \\
\hline 1 & Penghasilan per bulan & \multicolumn{1}{|c|}{$1.000 .000-1.100 .000$} & Sangat Baik & 1 \\
& & $1.200 .000-1.300 .000$ & Baik & Cukup \\
& & & & 0.8 \\
& & & & 0.6 \\
\hline 2 & Status Tanah & Status kepimilikan tanah(Milik & Milik Sendiri & 1 \\
& & Sendiri atau Milik Pemerintah) & Milik Pemerintah & 0 \\
\hline 3 & Jenis Atap & Seng Gelombang & Layak & 1 \\
& & Genteng,Multiroof & Tidak Layak & 0 \\
\hline 4 & Jenis lantai & Tanah & Sangat Baik & 1 \\
& & Papan & Baik & 0.8 \\
& & Rabat Beton & Cukup & 0.6 \\
& & & Sangat Baik & 1 \\
\hline 5 & Jenis Dinding & Gedek & Baik & 0.8 \\
& & Papan & Cukup & 0.6 \\
& & Papan + Gedek & Kurang & 0.4 \\
& & Papan + Bata & Sangat Kurang & 0.2 \\
\hline 6 & & Papan + Bata + Gedek & Layak & 1 \\
& & Tidak & Tidak Layak & 0 \\
\hline
\end{tabular}

Pada tabel 2 dan 2 merupakan data awal atau data mentah calon penerima bantuan renovasi rumah yang diambil dari hasil peninjauan oleh tim bedah rumah Nagori Tangga Batuyang terdiri dari 6 kriteria yaitu : Penghasilan perbulan, status tanah, jenis lantai, jenis dinding, MCK, dan jenis atap.

Tabel 2. Data Calon Penerima Bantuan Renovasi Rumah Pada Kantor Pangulu Nagori Tangga Batu

\begin{tabular}{|c|c|c|c|c|c|c|c|}
\hline No. & Nama & $\begin{array}{l}\text { Penghasilan } \\
\text { perbulan (Rp.) }\end{array}$ & $\begin{array}{l}\text { Status } \\
\text { Tanah }\end{array}$ & $\begin{array}{c}\text { Jenis } \\
\text { Lantai }\end{array}$ & $\begin{array}{c}\text { Jenis } \\
\text { Dinding }\end{array}$ & MCK & $\begin{array}{l}\text { Jenis } \\
\text { Atap }\end{array}$ \\
\hline 1 & Sumarlin sinaga & $\mathrm{B}$ & MS & $\mathrm{C}$ & $\mathrm{B}$ & $\mathrm{L}$ & $\mathrm{L}$ \\
\hline 2 & Parningotan sinaga & B & MS & $\mathrm{C}$ & B & $\mathrm{L}$ & $\mathrm{L}$ \\
\hline 3 & Delfi silalahi & $\mathrm{B}$ & MS & $\mathrm{C}$ & $\mathrm{B}$ & $\mathrm{L}$ & $\mathrm{L}$ \\
\hline 4 & Togar dohar situmorang & $\mathrm{C}$ & MS & $\mathrm{C}$ & B & $\mathrm{L}$ & $\mathrm{L}$ \\
\hline 5 & Marlinda ria siahaan & SB & MS & $\mathrm{C}$ & SB & $\mathrm{L}$ & $\mathrm{L}$ \\
\hline 6 & $\begin{array}{l}\text { Jonson parlindungan } \\
\text { silalahi }\end{array}$ & B & MS & $\mathrm{C}$ & B & $\mathrm{L}$ & $\mathrm{L}$ \\
\hline 7 & Sanra sinaga & $\mathrm{C}$ & MS & SB & B & $\mathrm{L}$ & $\mathrm{L}$ \\
\hline 8 & Tiolom silalahi & B & MS & $\mathrm{C}$ & $\mathrm{K}$ & $\mathrm{L}$ & $\mathrm{L}$ \\
\hline 9 & Hitler saragi & $\mathrm{C}$ & MS & $\mathrm{C}$ & $\mathrm{B}$ & $\mathrm{L}$ & $\mathrm{L}$ \\
\hline 10 & Arifson silalahi & $\mathrm{C}$ & MS & $\mathrm{C}$ & $\mathrm{B}$ & $\mathrm{L}$ & $\mathrm{L}$ \\
\hline 11 & Darwin nainggolan & SB & MS & $\mathrm{C}$ & $\mathrm{B}$ & $\mathrm{L}$ & $\mathrm{L}$ \\
\hline 12 & Riswanto siahaan & $\mathrm{C}$ & MS & $\mathrm{C}$ & $\mathrm{K}$ & $\mathrm{L}$ & $\mathrm{L}$ \\
\hline 13 & Rostianna pandiangan & SB & MS & $\mathrm{C}$ & $B$ & $\mathrm{~T}$ & $\mathrm{~L}$ \\
\hline 14 & Rantonius silalahi & B & MS & $\mathrm{C}$ & B & $\mathrm{T}$ & $\mathrm{L}$ \\
\hline 15 & Bentul siadari & $\mathrm{B}$ & MS & $\mathrm{C}$ & $\mathrm{K}$ & $\mathrm{T}$ & $\mathrm{L}$ \\
\hline 16 & Ramli manik & $\mathrm{C}$ & MS & $\mathrm{C}$ & $\mathrm{K}$ & $\mathrm{L}$ & $\mathrm{L}$ \\
\hline 17 & Ramli siallagan & B & MS & $\mathrm{C}$ & B & $\mathrm{T}$ & $\mathrm{L}$ \\
\hline 18 & Susanti & $\mathrm{C}$ & MS & $\mathrm{C}$ & $\mathrm{K}$ & $\mathrm{T}$ & $\mathrm{L}$ \\
\hline 19 & Muhadi & B & MS & $\mathrm{C}$ & $\mathrm{K}$ & $\mathrm{T}$ & $\mathrm{L}$ \\
\hline 20 & Ponisah & B & MS & $\mathrm{C}$ & $\mathrm{K}$ & $\mathrm{L}$ & $\mathrm{L}$ \\
\hline 21 & Ramaisi nainggolan & $\mathrm{B}$ & MS & $\mathrm{C}$ & $\mathrm{K}$ & $\mathrm{T}$ & $\mathrm{L}$ \\
\hline
\end{tabular}


Tabel 3. Data Calon Penerima Bantuan Renovasi Rumah Pada Kantor Pangulu Nagori Tangga Batu

\begin{tabular}{|c|l|c|c|c|c|c|c|}
\hline No & \multicolumn{1}{|c|}{ Nama } & $\begin{array}{c}\text { Penghasilan } \\
\text { perbulan (Rp.) }\end{array}$ & $\begin{array}{c}\text { Status } \\
\text { Tanah }\end{array}$ & $\begin{array}{c}\text { Jenis } \\
\text { Lantai }\end{array}$ & $\begin{array}{c}\text { Jenis } \\
\text { Dinding }\end{array}$ & MCK & $\begin{array}{c}\text { Jenis } \\
\text { Atap }\end{array}$ \\
\hline 1 & Supina & C & MS & C & B & T & L \\
\hline 2 & Paimun & C & MS & C & B & T & L \\
\hline 3 & Rukimin & B & MS & C & B & T & L \\
\hline 4 & Jimson manurung & C & MS & C & SK & T & L \\
\hline 5 & Asina rumahorbo & B & MS & C & K & L & L \\
\hline 6 & Rotua silalahi & B & MS & B & B & L & L \\
\hline 7 & Parlindungan simanjuntak & B & MS & C & K & L & L \\
\hline 8 & Sarmin & C & MS & C & K & L & L \\
\hline 9 & Herbin manurung & B & MS & B & B & L & L \\
\hline 10 & Nurhayati saragi & B & MS & C & B & L & L \\
\hline 11 & Saurma nainggolan & SB & MS & C & K & L & L \\
\hline 12 & Sarinah & B & MS & C & B & L & L \\
\hline 13 & Satini & B & MS & C & SK & L & L \\
\hline 14 & Amron sinaga & B & MS & C & B & T & L \\
\hline 15 & Sahat sirait & SB & MS & C & B & T & L \\
\hline 16 & Osbiner nainggolan & B & MS & C & B & L & L \\
\hline 17 & Selamat & B & MS & C & SB & L & L \\
\hline 18 & Saminah & B & MS & SB & C & L & L \\
\hline 19 & Nurdina damanik & B & MS & SB & K & L & L \\
\hline 20 & Yuliani & B & MS & C & B & T & L \\
\hline 21 & Suarmi & B & MS & SB & SB & T & L \\
\hline
\end{tabular}

Keterangan :

$\begin{array}{ll}\text { SB }=\text { Sangat Baik } & \text { B = Baik C = Cukup } \\ \mathrm{K}=\text { Kurang } & \text { SK = Sangat Kurang } \\ \mathrm{L}=\text { Layak } & \text { TL = Tidak Layak } \\ \text { MS = Milik Sendiri } & \text { MP = Milik Pemerintah }\end{array}$

\subsection{Rumah}

Rumah merupakan salah satu kebutuhan pokok bagi manusia, dimana rumah berperan sebagai wadah untuk bernaung dan tempat berlindung. Selain memiliki fungsi sebagai tempat tinggal, rumah juga berfungsi untuk tempat pembinaan dan bercengkrama suatu keluarga. Setiap manusia pasti berkeinginan memiliki rumah yang layak untuk ditinggali, agar penghuni rumah merasa aman dan nyaman saat menempati rumahnya. Namun keinginan memiliki rumah yang layak bagi beberapa orang harus terpendam disebabkan oleh kemiskinan.

\subsection{Algoritma Backpropogation}

Backpropagation merupakan algoritma pembelajaran yang terawasi dan baisanya digunakan oleh perceptron dengan banyak lapisan untuk mengubah bobot-bobot yang berhubungan dengan neuron-neuron yang ada pada lapisan tersembunyinya. Algoritma backpropagation menggunakan error output untuk mengubah nilai bobot-bobotnya dalam arah mundur (backward) [12]-[25]. Untuk mendapatkan error ini, tahap perambatan maju (forward propagation) harus dikerjakan terlebih dahulu[26]. 
Backpropagation adalah salah satu model JST yang mempunyai kemampuan mendapatkan keseimbangan antara kemampuan jaringan untuk mengenali pola yang digunakan selama pelatihan serta kemampuan jaringan untuk memberikan respon yang benar terhadap pola masukan yang serupa (tapi tidak sama) dengan pola yang dipakai selama pelatihan[27].

Langkah-langkah dalam algoritma backpropagation oleh[28] adalah sebagai berikut:

Langkah 0 : Inisialisasi bobot (set bobot pada nilai random yang kecil).

Langkah 1 : Ketika pada kondisi berhenti salah, lakukan langkah 2 - 9.

Langkah 2 : Untuk setiap pasangan training, lakukan langkah 3 - 8.

Langkah 3 : Setiap unit input $(X i, i=1, \ldots, n)$ menerima sinyal input Xi dan memancarkan sinyal ini kepada semua unit pada lapisan diatasnya (hidden unit)

Langkah $4 \quad$ : Setiap hidden unit $(Z j, j=1, \ldots, p)$ menjumlahkan bobot sinyal input

$$
\mathrm{z}_{-i n_{0}}=V_{0 j}+\sum_{i=1}^{n} X_{n} V_{i j}
$$

mengaplikasikan fungsi aktivasi untuk menghitung sinyal output.

$$
Z_{j=f\left(z_{-} i n_{j}\right)}
$$

dan mengirim sinyal ke semua unit di lapisan di atasnya (output unit).

Langkah 5 : Setiap unit output $(Y k, k=1, \ldots, m)$ menjumlahkan bobot sinyal input.

$$
y_{-i n_{k}}=W_{0 k}+\sum_{j=1}^{p} Z_{j} W_{j k}
$$

dan mengaplikasikan fungsi aktivasinya untuk menghitung sinyal output.

$$
Y_{k=f\left(y_{-} i n_{k}\right)}
$$

Langkah 6 : Setiap unit output $(Y k, k=1, \ldots, m)$ menerima pola target sesuai dengan pola training input, menghitung informasi error.

$$
\delta_{k=\left(t_{k}-y_{k}\right) f\left(y-y_{i} i_{k}\right)}
$$

menghitung koreksi bobotnya (digunakan untuk memperbaharui wjk)

$$
\Delta W_{o k=a} \delta_{k} Z_{j}
$$

menghitung koreksi bias (digunakan untuk memperbaharui w0k)

$$
\Delta \boldsymbol{W}_{\text {ok }=a} \boldsymbol{\delta}_{k}
$$

Langkah 7 : Setiap hidden unit $(Z j, j=1, \ldots, p)$ menjumlahkan delta input (dari unit di lapisan atas).

$$
\delta_{-i n_{f}}=\sum_{k=1}^{m} \delta_{k} W_{j k}
$$

dikalikan dengan turunan dari fungsi aktivasi untuk menghitung informasi error.

$$
\delta_{j=\delta_{-} i n_{f} f r\left(Z_{-} i n_{j}\right.}
$$


menghitung koreksi bobot (digunakan untuk memperbaharui vij)

$$
\Delta \boldsymbol{V}_{i j=a} \delta_{j} \boldsymbol{X}_{i}
$$

dan menghitung koreksi bias (digunakan untuk memperbaharui $\mathrm{v} 0 \mathrm{j})$

$$
\Delta V_{o j=a} \delta_{j}
$$

Langkah 8 : Setiap unit output $(Y k, k=1, \ldots, m)$ memperbaharui bias dan bobot $(\mathrm{j}=0, \ldots, \mathrm{p})$

$$
W_{j k}(\text { baru })=W_{j k}(\text { lama })+\Delta W_{j k}
$$

Setiap hidden unit $(Z j, j=1, \ldots, p)$ memperbaharui bobot dan bias $(i$ $=0, \ldots, n)$

$$
V_{j k}(\text { baru })=V_{j k}(\text { lama })+\Delta V_{j k}
$$

Langkah 9 : Tes kondisi berhenti.

\section{HASIL DAN PEMBAHASAN}

\subsection{Analisa Algoritma Backpropogation}

Dari hasil pengolahan data yang dilakukan, maka data calon penerima bantuan renovasi rumah pada Kantor Pangulu Nagori Tangga Batu yang sudah diolah seperti yang terdapat pada Tabel 4 dan Tabel 5 berikut:

Tabel 4. Hasil Data Calon Penerima Bantuan Renovasi Rumah Pada Kantor Pangulu Nagori Tangga Batu

\begin{tabular}{|c|l|c|c|c|c|c|c|}
\hline No & \multicolumn{1}{|c|}{ Nama } & $\begin{array}{c}\text { Penghasilan } \\
\text { PerBulan } \\
\text { (Rp.) }\end{array}$ & $\begin{array}{c}\text { Status } \\
\text { Tanah }\end{array}$ & $\begin{array}{c}\text { Jenis } \\
\text { Lantai }\end{array}$ & $\begin{array}{c}\text { Jenis } \\
\text { Dinding }\end{array}$ & MCK & $\begin{array}{c}\text { Jenis } \\
\text { Atap }\end{array}$ \\
\hline 1 & Sumarlin sinaga & 0.8 & 1 & 0.6 & 0.8 & 1 & 1 \\
\hline 2 & Parningotan sinaga & 0.8 & 1 & 0.6 & 0.8 & 1 & 1 \\
\hline 3 & Delfi silalahi & 0.8 & 1 & 0.6 & 0.8 & 1 & 1 \\
\hline 4 & $\begin{array}{l}\text { Togar dohar } \\
\text { situmorang }\end{array}$ & 0.6 & 1 & 0.6 & 0.8 & 1 & 1 \\
\hline 5 & Marlinda ria siahaan & 1 & 1 & 0.6 & 1 & 1 & 1 \\
\hline 6 & Jonson parlindungan & 0.8 & 1 & 0.6 & 0.8 & 1 & 1 \\
\hline 7 & Silalahi & 0.6 & 1 & 1 & 0.8 & 1 & 1 \\
\hline 8 & Tiolom silalahi & 0.8 & 1 & 0.6 & 0.4 & 1 & 1 \\
\hline 9 & Hitler saragi & 0.6 & 1 & 0.6 & 0.8 & 1 & 1 \\
\hline 10 & Arifson silalahi & 0.6 & 1 & 0.6 & 0.8 & 1 & 1 \\
\hline 11 & Darwin nainggolan & 1 & 1 & 0.6 & 0.8 & 1 & 1 \\
\hline 12 & Riswanto siahaan & 0.6 & 1 & 0.6 & 0.4 & 1 & 1 \\
\hline 13 & Rostianna & 1 & 1 & 0.6 & 0.8 & 0 & 1 \\
\hline 14 & pandiangan & & & & & & \\
\hline 15 & Bantonius silalahi & 0.8 & 1 & 0.6 & 0.8 & 0 & 1 \\
\hline 16 & Ramli manik & 0.8 & 1 & 0.6 & 0.4 & 0 & 1 \\
\hline 17 & Ramli siallagan & 0.6 & 1 & 0.6 & 0.4 & 1 & 1 \\
\hline 18 & Susanti & 0.8 & 1 & 0.6 & 0.8 & 0 & 1 \\
\hline 19 & Muhadi & 0.8 & 1 & 0.6 & 0.4 & 0 & 1 \\
\hline 20 & Ponisah & 0.8 & 1 & 0.6 & 0.4 & 1 & 1 \\
\hline 21 & Ramaisi nainggolan & 0.8 & 1 & 0.6 & 0.4 & 0 & 1 \\
\hline
\end{tabular}

Tabel 5. Hasil Data Calon Penerima Bantuan Renovasi Rumah Pada Kantor Pangulu Nagori Tangga Batu 


\begin{tabular}{|c|l|c|c|c|c|c|c|}
\hline No & \multicolumn{1}{|c|}{ Nama } & $\begin{array}{c}\text { Penghasilan } \\
\text { Per Bulan } \\
\text { (Rp.) }\end{array}$ & $\begin{array}{c}\text { Status } \\
\text { Tanah }\end{array}$ & $\begin{array}{c}\text { Jenis } \\
\text { Lantai }\end{array}$ & $\begin{array}{c}\text { Jenis } \\
\text { Dinding }\end{array}$ & MCK & $\begin{array}{c}\text { Jenis } \\
\text { Atap }\end{array}$ \\
\hline 1 & Supina & 0.6 & 1 & 0.6 & 0.8 & 0 & 1 \\
\hline 2 & Paimun & 0.6 & 1 & 0.6 & 0.8 & 0 & 1 \\
\hline 3 & Rukimin & 0.8 & 1 & 0.6 & 0.8 & 0 & 1 \\
\hline 4 & Jimson manurung & 0.6 & 1 & 0.6 & 0.2 & 0 & 1 \\
\hline 5 & Asina rumahorbo & 0.8 & 1 & 0.6 & 0.4 & 1 & 1 \\
\hline 6 & Rotua silalahi & 0.8 & 1 & 0.8 & 0.8 & 1 & 1 \\
\hline 7 & Parlindungan & 0.8 & 1 & 0.6 & 0.4 & 1 & 1 \\
\hline 8 & Simanjuntak & & & & & & \\
\hline 9 & Sarmin & 0.6 & 1 & 0.6 & 0.4 & 1 & 1 \\
\hline 10 & Nurbin manati saragi & 0.8 & 1 & 0.8 & 0.8 & 1 & 1 \\
\hline 11 & Saurma nainggolan & 0.8 & 1 & 0.6 & 0.8 & 1 & 1 \\
\hline 12 & Sarinah & 1 & 1 & 0.6 & 0.4 & 1 & 1 \\
\hline 13 & Satini & 0.8 & 1 & 0.6 & 0.8 & 1 & 1 \\
\hline 14 & Amron sinaga & 0.8 & 1 & 0.6 & 0.2 & 1 & 1 \\
\hline 15 & Sahat sirait & 0.8 & 1 & 0.6 & 0.8 & 0 & 1 \\
\hline 16 & Osbiner nainggolan & 1 & 1 & 0.6 & 0.8 & 0 & 1 \\
\hline 17 & Selamat & 0.8 & 1 & 0.6 & 0.8 & 1 & 1 \\
\hline 18 & Saminah & 0.8 & 1 & 0.6 & 1 & 1 & 1 \\
\hline 19 & Nurdina damanik & 0.8 & 1 & 1 & 0.6 & 1 & 1 \\
\hline 20 & Yuliani & 0.8 & 1 & 1 & 0.4 & 1 & 1 \\
\hline 21 & Suarmi & 0.8 & 1 & 0.6 & 0.8 & 0 & 1 \\
\hline
\end{tabular}

Hasil yang diinginkan pada tahap ini adalah terdeteksinya suatu nilai untuk penentuan apakah calon penerima bantuan renovasi rumah tersebut kategori layak atau tidak. Kategorisasi layak ditentukan oleh tingkat error minimum dari target layak dan tidak layak yaitu: Kategorisasi layak dan tidak layak dapat dilihat pada tabel 6 :

Tabel 6. Data Kategorisasi Layak dan Tidak Layak

\begin{tabular}{|c|c|c|c|}
\hline No & Keterangan & Bobot & Error Minimum \\
\hline 1 & Layak & 1 & $0,0011-0,0100$ \\
\hline 2 & Tidak Layak & 0 & $0.0101-0.1000$ \\
\hline
\end{tabular}

Algoritma pelatihan backpropagation dengan menggunakan 6 input layer, 2 layer tersembunyi, 1 outputlayer dengan fungsi aktivasi sigmoid biner adalah sebagai berikut :

1. Tahap inialisasi :

a. Tuliskan nilai input yang diberikan

$$
\begin{array}{llrl}
X_{1}=0.8 \quad X_{2} & =1 & X_{3} & =0.6 \\
X_{4}=0.8 \quad X_{5} & =1 \quad X_{6}=1 \\
T=1 & \text { Leraning } & \text { rate }(\alpha)=0.1
\end{array}
$$

b. Berikan nilai bobot $(V)$ dari input ke lapisan tersembunyi dengan nilai acak.

Tabel 7. Nilai Bobot dari Input ke HiddenLayer

\begin{tabular}{|c|c|c|}
\hline Kriteria & $K_{1}$ & $K_{2}$ \\
\hline$X_{1}$ & 4,7457 & 4,7785 \\
\hline$X_{2}$ & 0 & 0 \\
\hline
\end{tabular}




\begin{tabular}{|c|c|c|}
\hline Kriteria & $K_{1}$ & $K_{2}$ \\
\hline$X_{3}$ & $-5,6246$ & 4,8678 \\
\hline$X_{4}$ & 1,3305 & $-3,1595$ \\
\hline$X_{5}$ & $-1,3360$ & 0,2208 \\
\hline$X_{6}$ & 0 & 0 \\
\hline
\end{tabular}

c. Berikan nilai bobot $(W)$ dari lapisan tersembunyi ke output dengan nilai acak.

Tabel 8. Nilai Bobot dari HiddenLayer ke Output

\begin{tabular}{|c|c|}
\hline Hidden Layer & $L$ \\
\hline$K_{1}$ & 1,9640 \\
\hline$K_{2}$ & 1,9957 \\
\hline
\end{tabular}

2. Iterasi 1

a. Hitung keluaran tiap node (node tersembunyi dan nodeoutput)

$$
\begin{aligned}
& K 1=X_{1} . V_{11}+X_{2} . V_{21}+X_{3} . V_{31+} X_{4} \cdot V_{41+} X_{5} . V_{51+} X_{6} . V_{61} \\
& =0,8 \cdot 4,7457+1 \cdot 0+0,6 \cdot-5,6246+0,8 \cdot 1,3305+1 .-1,3360+1 \cdot 0 \\
& =0,1502 \\
& =\text { Sigmoid }[0,1502]=\frac{1}{\left(1+e^{0,1502}\right)}=0,4625 \\
& K 2=X_{1}, V_{12+} X_{2} \cdot V_{22+} X_{3} \cdot V_{32+} X_{4} \cdot V_{42+} X_{5}, V_{52+} X_{6} \cdot V_{62} \\
& =0,8 \cdot 4,7785+1.0+0,6 \cdot 4,8678+0,8 \cdot-3,1595+1.0,2208+1 \cdot 0 \\
& =4,4367 \\
& =\text { Sigmoid }[4,4367]=\frac{1}{\left(1+e^{4,4867}\right)}=0,0117 \\
& L=K 1 \cdot W_{11+} K 2 \cdot W_{21} \\
& =0,4625 \cdot 1,9640+0,0117 \cdot 1,9957 \\
& =0,9317 \\
& =\text { Sigmoid }[0,9317]=\frac{1}{1+\theta^{(0,9817)}}=0,2826
\end{aligned}
$$

b. Hitung nilai error outputdan hidden layer

Rumus mencari error output layer:

$$
\operatorname{Err}_{i}=O_{i}\left(1-O_{i}\right)\left(T_{i}-O_{i}\right)
$$

Rumus mencari error hidden layer:

$$
\begin{aligned}
\operatorname{Err}_{j} & =O_{i}\left(1-O_{i}\right) \sum_{j} \operatorname{Err}_{j} w_{i j} \\
\operatorname{Err} L & =L \cdot(\alpha-L) \cdot(T-L) \\
& =0,2826 \cdot(0 \cdot 1-0,2826) \cdot(1-0,2826) \\
& =-0,0370 \\
\operatorname{ErrK1} & =K 1 \cdot(\alpha-K 1) \cdot\left(\operatorname{Err} L-W_{11}\right) \\
& =0,4625 \cdot(0 \cdot 1-0,4625) \cdot(-0,0370-(1,9640)) \\
& =0,3355 \\
\operatorname{Err} K 2 & =K 2 \cdot(\alpha-K 2) \cdot\left(\operatorname{Err} L-\mathrm{W}_{21}\right) \\
& =0,0117 \cdot(0 \cdot 1-0,0117) \cdot(0,0370-(1,9957)) \\
& =-0,0021
\end{aligned}
$$

c. Modifikasi/hitung bobot baru

Rumus memodifikasi bobot baru : 


$$
\begin{aligned}
W_{i j} & =w_{i j}+l \cdot \operatorname{Err}_{j} \cdot O_{i} \\
\Delta W_{11} & =W_{11+} \alpha \cdot \operatorname{Err} L \cdot K 1 \\
& =1,964+0,1 \cdot 0,0370 \cdot 0,4625 \\
& =1,9623 \\
\Delta \mathrm{W}_{21} & =\mathrm{W}_{21+} \alpha \cdot \operatorname{Err} L \cdot \mathrm{K} 2 \\
& =1,9957+0,1 \cdot 0,0370 \cdot 0 \cdot 0117 \\
& =1,9957 \\
\Delta \mathrm{V}_{11} & =\mathrm{V}_{11+} \alpha \cdot \operatorname{Err} \text { K1. } \mathrm{X}_{1} \\
& =4,7457+0,1 \cdot 0,3355 \cdot 0,8000 \\
& =4,7725 \\
\Delta \mathrm{V}_{12} & =\mathrm{V}_{12+} \alpha \cdot \operatorname{Err} K 2 \cdot \mathrm{X}_{1} \\
& =4,7785+0,1 \cdot-0,0021 \cdot 0,8000 \\
& =4,7783
\end{aligned}
$$

dari hasil data penelitian diatas,maka dapat dihasilkan nilai bobot baru sebagai beikut :

$$
\begin{aligned}
& \Delta W_{11}=1,9623 \\
& \Delta W_{21}=1,9957 \\
& \Delta V_{11}=4,7725 \\
& \Delta V_{12}=4,7783
\end{aligned}
$$

Sehingga nilai outputlayer $(L)$ dari hasil pelatihan adalah $=0,2826$ dan angka ini menunjukan bahwa error $(e)$ antara target dengan outputlayer adalah $=0,7174$. Jika dihubungkan dengan penelitian tentang penentuan kelayakan calon penerima bantuan renovasi rumah,disimpulkanbahwa masih belum akurat pola atau penentuan kelayakan calon penerima bantuan renovasi rumah. Tabel data yang akan dilatih dan diujikan dapat dilihat pada tabel 9 dan tabel 10.

Tabel 9. Data Pelatihan Permohonan Calon Penerima Bantuan Renovasi Rumah Pada Kantor Pangulu Nagori Tangga Batu

\begin{tabular}{|c|l|c|c|c|c|c|c|c|}
\hline No & \multicolumn{1}{|c|}{ Nama } & $\begin{array}{c}\text { Penghasila } \\
\text { n Per } \\
\text { Bulan (Rp.) }\end{array}$ & $\begin{array}{c}\text { Status } \\
\text { Tanah }\end{array}$ & $\begin{array}{c}\text { Jenis } \\
\text { Lant } \\
\text { ai }\end{array}$ & $\begin{array}{c}\text { Jenis } \\
\text { Dinding }\end{array}$ & $\begin{array}{c}\text { MC } \\
\text { K }\end{array}$ & $\begin{array}{c}\text { Jenis } \\
\text { Atap }\end{array}$ & $\begin{array}{c}\text { Targ } \\
\text { et }\end{array}$ \\
\hline 1 & Sumarlin sinaga & 0.8 & 1 & 0.6 & 0.8 & 1 & 1 & 1 \\
\hline 2 & Parningotan sinaga & 0.8 & 1 & 0.6 & 0.8 & 1 & 1 & 1 \\
\hline 3 & Delfi silalahi & 0.8 & 1 & 0.6 & 0.8 & 1 & 1 & 1 \\
\hline 4 & $\begin{array}{l}\text { Togar dohar } \\
\text { situmorang }\end{array}$ & 0.6 & 1 & 0.6 & 0.8 & 1 & 1 & 1 \\
\hline 5 & Marlinda ria siahaan & 1 & 1 & 0.6 & 1 & 1 & 1 & 1 \\
\hline$\ldots$ & $\ldots$ & $\ldots$ & $\ldots$ & $\ldots$ & $\ldots$ & $\ldots$ & $\ldots$ & $\ldots$ \\
\hline 20 & Ponisah & 0.8 & 1 & 0.6 & 0.4 & 1 & 1 & 1 \\
\hline 21 & Ramaisi nainggolan & 0.8 & 1 & 0.6 & 0.4 & 0 & 1 & 1 \\
\hline
\end{tabular}

Tabel 10. Data Pengujian Permohonan Calon Penerima Bantuan Renovasi Rumah Pada Kantor Pangulu Nagori Tangga Batu

\begin{tabular}{|c|l|c|c|c|c|c|c|c|}
\hline No & \multicolumn{1}{|c|}{ Nama } & $\begin{array}{c}\text { Penghasilan } \\
\text { per bulan } \\
\text { (Rp.) }\end{array}$ & $\begin{array}{c}\text { Status } \\
\text { Tanah }\end{array}$ & $\begin{array}{c}\text { Jenis } \\
\text { Lantai }\end{array}$ & $\begin{array}{c}\text { Jenis } \\
\text { Dinding }\end{array}$ & MCK & $\begin{array}{c}\text { Jenis } \\
\text { Atap }\end{array}$ & $\begin{array}{c}\text { Targ } \\
\text { et }\end{array}$ \\
\hline 1 & Supina & 0.6 & 1 & 0.6 & 0.8 & 0 & 1 & 1 \\
\hline 2 & Paimun & 0.6 & 1 & 0.6 & 0.8 & 0 & 1 & 1 \\
\hline
\end{tabular}




\begin{tabular}{|c|l|c|c|c|c|c|c|c|}
\hline No & \multicolumn{1}{|c|}{ Nama } & $\begin{array}{c}\text { Penghasilan } \\
\text { per bulan } \\
\text { (Rp.) }\end{array}$ & $\begin{array}{c}\text { Status } \\
\text { Tanah }\end{array}$ & $\begin{array}{c}\text { Jenis } \\
\text { Lantai }\end{array}$ & $\begin{array}{c}\text { Jenis } \\
\text { Dinding }\end{array}$ & MCK & $\begin{array}{c}\text { Jenis } \\
\text { Atap }\end{array}$ & $\begin{array}{c}\text { Targ } \\
\text { et }\end{array}$ \\
\hline 3 & Rukimin & 0.8 & 1 & 0.6 & 0.8 & 0 & 1 & 1 \\
\hline 4 & $\begin{array}{l}\text { Jimson } \\
\text { manurung }\end{array}$ & 0.6 & 1 & 0.6 & 0.2 & 0 & 1 & 1 \\
\hline 5 & $\begin{array}{l}\text { Asina } \\
\text { rumahorbo }\end{array}$ & 0.8 & 1 & 0.6 & 0.4 & 1 & 1 & 1 \\
\hline$\ldots$ & $\ldots$ & $\ldots$ & $\ldots$ & $\ldots$ & $\ldots$ & $\ldots$ & $\ldots$ & $\ldots$ \\
\hline 20 & Yuliani & 0.8 & 1 & 0.6 & 0.8 & 0 & 1 & 1 \\
\hline 21 & Suarmi & 0.8 & 1 & 1 & 1 & 0 & 1 & 1 \\
\hline
\end{tabular}

Data yang akan diolah menggunakan matlab dengan pola arsitektur 6-2-1, dengan data pelatihan sebanyak 21 calon penerima bantuan renovasi rumah pada tabel 9 dari nomor 1 sampai dengan 21. Untuk melihat hasil yang dikeluarkan oleh jaringan dapat menggunakan perintah sebagai berikut: $>>[a, P f, A f, e, P e r f]=\operatorname{sim}($ net,p, []$,[], t)$

Setelah dilakukan perulangan maka ditemukan error minimum pada epoch 866 seperti pada gambar 2 . di bawah ini :

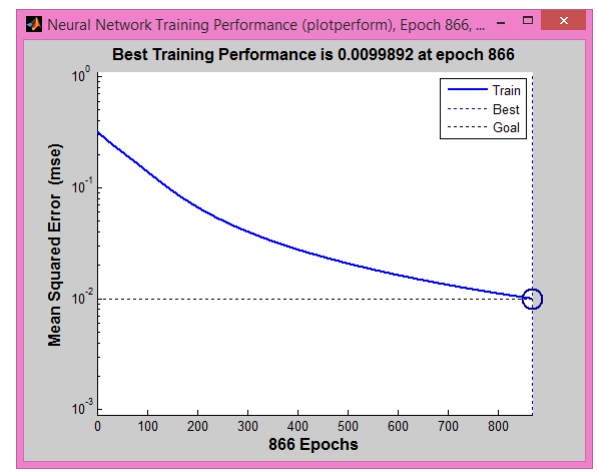

Gambar 2 Pelatihan Pola 6-2-1 Mencapai Goal

Adapun hasil yang lebih rinci output dan error dapat dilihat pada tabel 11 sebagai berikut :

Tabel 11. Hasil dan Error Data Input Pelatihan dengan Model $6-2-1$

\begin{tabular}{|c|c|c|c|c|c|c|c|c|c|}
\hline \multirow[t]{2}{*}{ No. } & \multicolumn{6}{|c|}{ Data Input Pelatihan } & \multirow[t]{2}{*}{ Target } & \multicolumn{2}{|c|}{ JST 6-2-1 } \\
\hline & $\mathrm{X1}$ & $\mathrm{X} 2$ & X3 & $\mathrm{X} 4$ & $\mathrm{X} 5$ & X6 & & Output & Error \\
\hline 1 & 0.8000 & 1.0000 & 0.6000 & 0.8000 & 1.0000 & 1.0000 & 1.0000 & 0.96890 & 0.03110 \\
\hline 2 & 0.8000 & 1.0000 & 0.6 & 0.8 & 1.0000 & 1.0000 & & 0.96890 & 0.03110 \\
\hline 3 & 0.8000 & 1.0000 & 0.6 & 0.8 & 1.0000 & 1.0000 & 1. & 0.96890 & 0.03110 \\
\hline 4 & 0.6000 & 1.0000 & 0.6000 & 0.8000 & 1.0000 & 1.0000 & 1.0000 & 0.84345 & 0.15655 \\
\hline 5 & 1.0000 & 1.0000 & 0.6000 & 1.0000 & 1.0000 & 1.0000 & 1.0000 & 0.98691 & 0.01309 \\
\hline$\ldots$ & & $\ldots$ & & & 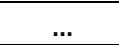 & & & ... & \\
\hline 20 & 0.8000 & 1.0000 & 0.6000 & 0.4000 & 1.0000 & 1.0000 & 1.0000 & 0.92811 & 0.07189 \\
\hline 21 & 0.8000 & 1.0000 & 0.6000 & 0.4000 & 0.0000 & 1.0000 & 1.0000 & 0.98184 & 0.01816 \\
\hline
\end{tabular}

Setelah dilakukan pelatihan dengan pola arsitektur 6-2-1, maka dilanjutkan dengan pengujian dengan data pengujian sebanyak 21 calon penerima bantuan renovasi rumah pada tabel 10 nomor 1 sampai dengan 21. 
Berikut adalah hasil pengujian dengan 21 data pengujian dengan pola pengujian 6-2-1. Data hasil pengujian dapat dilihat pada tabel 12 sebagai berikut:

Tabel 12. Hasil dan Error Data Input Pengujian dengan Model $6-2-1$

\begin{tabular}{|c|c|c|c|c|c|c|c|c|c|}
\hline \multirow{2}{*}{ No. } & \multicolumn{6}{|c|}{ Data Input Pengujian } & Target & \multicolumn{2}{|c|}{ JST 6-2-1 } \\
\cline { 2 - 9 } & $\mathbf{X 1}$ & $\mathbf{X 2}$ & $\mathbf{X 3}$ & $\mathbf{X 4}$ & $\mathbf{X 5}$ & $\mathbf{X 6}$ & & Output & Error \\
\hline 1 & 0.6000 & 1.0000 & 0.6000 & 0.8000 & 0.0000 & 1.0000 & 1.0000 & 0.93977 & 0.06023 \\
\hline 2 & 0.6000 & 1.0000 & 0.6000 & 0.8000 & 0.0000 & 1.0000 & 1.0000 & 0.93977 & 0.06023 \\
\hline 3 & 0.8000 & 1.0000 & 0.6000 & 0.8000 & 0.0000 & 1.0000 & 1.0000 & 0.98458 & 0.01542 \\
\hline 4 & 0.6000 & 1.0000 & 0.6000 & 0.2000 & 0.0000 & 1.0000 & 1.0000 & 0.90416 & 0.09584 \\
\hline 5 & 0.8000 & 1.0000 & 0.6000 & 0.4000 & 1.0000 & 1.0000 & 1.0000 & 0.92811 & 0.07189 \\
\hline$\ldots$ & $\ldots$ & $\ldots$ & $\ldots$ & $\ldots$ & $\ldots$ & $\ldots$ & $\ldots$ & $\ldots$ & $\ldots$ \\
\hline 20 & 0.8000 & 1.0000 & 0.6000 & 0.8000 & 0.0000 & 1.0000 & 1.0000 & 0.98458 & 0.01542 \\
\hline 21 & 0.8000 & 1.0000 & 1.0000 & 1.0000 & 0.0000 & 1.0000 & 1.0000 & 0.90877 & 0.09123 \\
\hline
\end{tabular}

Proses pengujian dilakukan dengan menggunakan software aplikasi Matlab R2011a Model Jaringan Syaraf Tiruan yang digunakan adalah 6-2-1, model 6-3-1, model 6-4-1 dan model 6-5-1. Untuk hasil perbandingan pengujian yang lebih rinci dapat dilihat pada tabel 13 sebagai berikut :

Tabel 13. Hasil Pengujian Sistem

\begin{tabular}{|c|c|c|c|c|c|c|c|c|c|c|c|c|}
\hline No & \multicolumn{3}{|c|}{$\begin{array}{c}\text { Pengujian dengan Matlab } \\
\text { Model 6-2-1 }\end{array}$} & \multicolumn{3}{|c|}{$\begin{array}{c}\text { Pengujian dengan Matlab } \\
\text { Model 6-3-1 }\end{array}$} & \multicolumn{3}{|c|}{$\begin{array}{c}\text { Pengujian dengan Matlab } \\
\text { Model 6-4-1 }\end{array}$} & \multicolumn{3}{|c|}{$\begin{array}{c}\text { Pengujian dengan Matlab } \\
\text { Model 6-5-1 }\end{array}$} \\
\hline 1 & 1 & 0.93977 & 0.06023 & 1 & 0.88696 & 0.11304 & 1 & 0.96912 & 0.03088 & 1 & 0.82838 & 0.17162 \\
\hline 3 & 1 & 0.98458 & 0.01542 & 1 & 0.85372 & 0.14628 & 1 & 0.95119 & 0.04881 & 1 & 0.94041 & 0.05959 \\
\hline 4 & 1 & 0.90416 & 0.09584 & 1 & 0.82571 & 0.17429 & 1 & 0.87991 & 0.12009 & 1 & 0.63687 & 0.36313 \\
\hline 5 & 1 & 0.92811 & 0.07189 & 1 & 0.98938 & 0.01062 & 1 & 0.96789 & 0.03211 & 1 & 0.98926 & 0.01074 \\
\hline 8 & 1 & 0.81725 & 0.18275 & 1 & 0.97708 & 0.02292 & 1 & 0.71756 & 0.28244 & 1 & 0.98409 & 0.01591 \\
\hline 9 & 1 & 0.87152 & 0.12848 & 1 & 0.99094 & 0.00906 & 1 & 0.96283 & 0.03717 & 1 & 0.98969 & 0.01031 \\
\hline 10 & 1 & 0.96890 & 0.03110 & 1 & 0.98252 & 0.01748 & 1 & 0.99237 & 0.00763 & 1 & 0.98818 & 0.01182 \\
\hline 11 & 1 & 0.98044 & 0.01956 & 1 & 0.99094 & 0.00906 & 1 & 0.99224 & 0.00776 & 1 & 0.98604 & 0.01396 \\
\hline 12 & 1 & 0.96890 & 0.03110 & 1 & 0.98252 & 0.01748 & 1 & 0.99237 & 0.00763 & 1 & 0.98818 & 0.01182 \\
\hline 13 & 1 & 0.89375 & 0.10625 & 1 & 0.99045 & 0.00955 & 1 & 0.82649 & 0.17351 & 1 & 0.98419 & 0.01581 \\
\hline 18 & 1 & 0.78668 & 0.21332 & 1 & 0.99160 & 0.00840 & 1 & 0.82783 & 0.17217 & 1 & 0.98957 & 0.01043 \\
\hline 19 & 1 & 0.78282 & 0.21718 & 1 & 0.99096 & 0.00904 & 1 & 0.89347 & 0.10653 & 1 & 0.98609 & 0.01391 \\
\hline 20 & 1 & 0.98458 & 0.01542 & 1 & 0.85372 & 0.14628 & 1 & 0.95119 & 0.04881 & 1 & 0.94041 & 0.05959 \\
\hline 21 & 1 & 0.90877 & 0.09123 & 1 & 0.90201 & 0.09799 & 1 & 0.81298 & 0.18702 & 1 & 0.98511 & 0.01489 \\
\hline
\end{tabular}

Dari keempat model yang digunakan penulis dalam proses pengujian sistem Jaringan Syaraf Tiruan dengan algoritma backpropagation dengan menggunakan Matlab R2011a dengan sampel data sebanyak 42 data calon penerima bantuan renovasi rumah, maka penulis menyimpulkan bahwa model terbaik adalah model 6-3-1 dengan proses perulangan (epoch) pada saat pelatihan dengan nilai epoch = 1673 dan pencapaian MSE pada saat pengujian dengan $\mathrm{MSE}=\mathbf{0 . 0 0 7 9 7 0 6 8}$. Adapun data perbandingan dari masing-masing model dapat dilihat pada tabel 14 di bawah ini : 
Tabel 14. Perbandingan Epoch dan MSE

\begin{tabular}{|l|c|c|c|c|}
\hline & $\mathbf{6 - 2 - 1}$ & $\mathbf{6 - 3 - 1}$ & $\mathbf{6 - 4 - 1}$ & $\mathbf{6 - 5 - 1}$ \\
\hline Epoch Pelatihan & 866 & 1673 & 745 & 1022 \\
\hline MSE Pengujian & 0.01001052 & 0.00797068 & 0.010389442 & 0.011290528 \\
\hline Akurasi & $100 \%$ & $100 \%$ & $100 \%$ & 100 \\
\hline
\end{tabular}

\section{KESIMPULAN}

Kesimpulan yang dapat diambil setelah melakukan pelatihan dan pengujian data pada jaringan syaraf tiruan dengan menggunakan algoritma backpropagation adalah sebagai berikut :

1. Jaringan Syaraf Tiruan dapat digunakan untuk menentukan kelayakan calon penerima bantuan renovasi rumah berdasarkan 6 kriteria sebagai masukan dari calon penerima bantuan renovasi rumah yaitu: Penghasilan perbulan, status tanah, jenis lantai, jenis dinding, MCK, dan jenis atap.

2. Akuratnya sebuah hasil pelatihan ataupun pengujian terhadap nilai output dalam menentukan kelayakan calon penerima bantuan renovasi rumah, tergantung pada pola arsitektur jaringan yang digunakan.

3. Arsitektur yang terbaik untuk penelitian metode Jaringan Syaraf Tiruan dalam menentukan kelayakan calon penerima bantuan renovasi rumah menggunakan algoritma backpropagation adalah model 6-3-1 dengan proses perulangan (epoch) pada saat pelatihan dengan nilai epoch $=1673$ dan pencapaian MSE pada saat pengujian dengan MSE $=\mathbf{0 . 0 0 7 9 7 0 6 8}$.

4. Hasil dari penelitian Jaringan Saraf Tiruan dapat tim bedah rumah mengetahui layak atau tidak warga Nagori Tangga Batu mendapatkan bantuan renovasi rumah.

\section{DAFTAR PUSTAKA}

[1] V. Listyaningsih, H. Setiawan, E. Sudrajat, and R. P. Kristianto, "Dss Pemilihan Penerima Bantuan Perbaikan Rumah Dengan Metode WEIGHTED PRODUCT," 2016.

[2] A. Wanto and A. P. Windarto, "Analisis Prediksi Indeks Harga Konsumen Berdasarkan Kelompok Kesehatan Dengan Menggunakan Metode Backpropagation," Jurnal \& Penelitian Teknik Informatika Sinkron, vol. 2, no. 2, pp. 37-44, 2017.

[3] A. Wanto, M. Zarlis, Sawaluddin, and D. Hartama, "Analysis of Artificial Neural Network Backpropagation Using Conjugate Gradient Fletcher Reeves in the Predicting Process," Journal of Physics: Conference Series, vol. 930, no. 1, pp. 1-7, 2017.

[4] A. Wanto, A. P. Windarto, D. Hartama, and I. Parlina, "Use of Binary Sigmoid Function And Linear Identity In Artificial Neural Networks For Forecasting Population Density," International Journal of Information System \& Technology, vol. 1, no. 1, pp. 43-54, 2017.

[5] S. P. Siregar and A. Wanto, "Analysis of Artificial Neural Network Accuracy Using Backpropagation Algorithm In Predicting Process (Forecasting)," International Journal Of Information System \& Technology, vol. 1, no. 1, pp. 34-42, 2017.

[6] J. R. Saragih, M. Billy, S. Saragih, and A. Wanto, "Analisis Algoritma Backpropagation Dalam Prediksi Nilai Ekspor (Juta USD)," Jurnal Pendidikan Teknologi dan Kejuruan, vol. 15, no. 2, pp. 254-264, 2018.

[7] E. Hartato, D. Sitorus, and A. Wanto, "Analisis Jaringan Saraf Tiruan Untuk Prediksi Luas Panen Biofarmaka di Indonesia," Jurnal semanTIK, vol. 4, no. 1, pp. 49-56, 2018.

[8] S. Setti and A. Wanto, "Analysis of Backpropagation Algorithm in Predicting the Most Number of Internet Users in the World," JOIN (Jurnal Online Informatika), vol. 3, no. 2, pp. 110-115, 2018.

[9] R. E. Pranata, S. P. Sinaga, and A. Wanto, "Estimasi Wisatawan Mancanegara Yang Datang ke Sumatera Utara Menggunakan Jaringan Saraf," Jurnal semanTIK, vol. 4, no. 1, pp. 97-102, 2018. 
[10] A. A. Fardhani, D. Insani, N. Simanjuntak, and A. Wanto, "Prediksi Harga Eceran Beras Di Pasar Tradisional Di 33 Kota Di Indonesia Menggunakan Algoritma Backpropagation," Jurnal Infomedia, vol. 3, no. 1, pp. 25-30, 2018.

[11] J. Wahyuni, Y. W. Paranthy, and A. Wanto, "Analisis Jaringan Saraf Dalam Estimasi Tingkat Pengangguran Terbuka Penduduk Sumatera Utara," Jurnal Infomedia, vol. 3, no. 1, pp. 18-24, 2018.

[12] A. Wanto et al., "Levenberg-Marquardt Algorithm Combined with Bipolar Sigmoid Function to Measure Open Unemployment Rate in Indonesia," in Conference Paper, 2018, pp. 1-7.

[13] I. A. R. Simbolon, F. Yatussa'ada, and A. Wanto, "Penerapan Algoritma Backpropagation dalam Memprediksi Persentase Penduduk Buta Huruf di Indonesia," Jurnal Informatika Upgris, vol. 4, no. 2, pp. 163-169, 2018.

[14] S. P. Siregar, A. Wanto, and Z. M. Nasution, "Analisis Akurasi Arsitektur JST Berdasarkan Jumlah Penduduk Pada Kabupaten / Kota di Sumatera Utara," in Seminar Nasional Sains \& Teknologi Informasi (SENSASI), 2018, pp. 526-536.

[15] A. Wanto, "Optimasi Prediksi Dengan Algoritma Backpropagation Dan Conjugate Gradient Beale-Powell Restarts," Jurnal Teknologi dan Sistem Informasi, vol. 3, no. 3, pp. 370-380, Jan. 2018.

[16] B. K. Sihotang and A. Wanto, "Analisis Jaringan Syaraf Tiruan Dalam Memprediksi Jumlah Tamu Pada Hotel Non Bintang," Jurnal Teknologi Informasi Techno, vol. 17, no. 4, pp. 333346, 2018.

[17] M. A. P. Hutabarat, M. Julham, and A. Wanto, "Penerapan Algoritma Backpropagation Dalam Memprediksi Produksi Tanaman Padi Sawah Menurut Kabupaten/Kota di Sumatera Utara," Jurnal semanTIK, vol. 4, no. 1, pp. 77-86, 2018.

[18] Y. Andriani, H. Silitonga, and A. Wanto, "Analisis Jaringan Syaraf Tiruan untuk prediksi volume ekspor dan impor migas di Indonesia," Register - Jurnal Ilmiah Teknologi Sistem Informasi, vol. 4, no. 1, pp. 30-40, 2018.

[19] A. Wanto, "Penerapan Jaringan Saraf Tiruan Dalam Memprediksi Jumlah Kemiskinan Pada Kabupaten/Kota Di Provinsi Riau," Kumpulan jurnaL Ilmu Komputer (KLIK), vol. 5, no. 1, pp. 61-74, 2018.

[20] I. S. Purba and A. Wanto, "Prediksi Jumlah Nilai Impor Sumatera Utara Menurut Negara Asal Menggunakan Algoritma Backpropagation," Jurnal Teknologi Informasi Techno, vol. 17, no. 3, pp. 302-311, 2018.

[21] A. Wanto, "Prediksi Angka Partisipasi Sekolah dengan Fungsi Pelatihan Gradient Descent With Momentum \& Adaptive LR," Jurnal Ilmu Komputer dan Informatika (ALGORITMA), vol. 3, no. 1, pp. 9-20, 2019.

[22] N. Nasution, A. Zamsuri, L. Lisnawita, and A. Wanto, "Polak-Ribiere updates analysis with binary and linear function in determining coffee exports in Indonesia," IOP Conference Series: Materials Science and Engineering, vol. 420, no. 12089, pp. 1-9, 2018.

[23] A. Wanto, "Prediksi Produktivitas Jagung Indonesia Tahun 2019-2020 Sebagai Upaya Antisipasi Impor Menggunakan Jaringan Saraf Tiruan Backpropagation," SINTECH (Science and Information Technology), vol. 1, no. 1, pp. 53-62, 2019.

[24] B. Febriadi, Z. Zamzami, Y. Yunefri, and A. Wanto, "Bipolar function in backpropagation algorithm in predicting Indonesia's coal exports by major destination countries," IOP Conference Series: Materials Science and Engineering, vol. 420, no. 12089, pp. 1-9, 2018.

[25] A. Wanto et al., "Analysis of Standard Gradient Descent with GD Momentum And Adaptive LR for SPR Prediction," 2018, pp. 1-9.

[26] D. H. Tanjung, "Jaringan Saraf Tiruan dengan Backpropagation untuk Memprediksi Penyakit Asma," Citec Journal, vol. 2, no. 1, pp. 28-38, 2015.

[27] A. Revi, Solikhun, and I. Parlina, "Jaringan Syaraf Tiruan Dalam Memprediksi Tingkat Pertumbuhan Industri Mikro Dan Kecil Berdasarkan Provinsi,” vol. 7, no. November, 2018.

[28] Solikhun, M. Safii, and A. Trisno, "JARINGAN SARAF TIRUAN UNTUK MEMPREDIKSI TINGKAT PEMAHAMAN SISWA TERHADAP MATAPELAJARAN DENGAN MENGGUNAKAN ALGORITMA BACKPROPOGATION," vol. 1, no. 1, pp. 24-36, 2017. 